\title{
THE SYNTHESIS AND THE REACTIVITY OF ARENE RUTHENIUM OXALATO COMPLEXES
}

\author{
Cheikh Mbacké Ndiaye*, Bamba Déthiélaw Dieng, Fatou Dieng Faye, Mohamed Gaye and \\ Abdoulaye Samb
}

Groupe de Synthèse Bioorganométallique, Laboratoire de Chimie et Biochimie des Produits Naturels, Département de Chimie/Faculté des Sciences et Techniques, Université Cheikh Anta Diop de Dakar, Sénégal

(Received May 8, 2007; revised September 10, 2007)

\begin{abstract}
This article outlines the reactions of the well known $\left[\mathrm{RuCl}\left(\eta^{6}-p \text {-cymene }\right)\right]_{2}\left(\mu-\eta^{4}-\mathrm{C}_{2} \mathrm{O}_{4}\right)$ and $\left[\mathrm{RuCl}\left(\eta^{6}-p\right.\right.$-cymene $)\left(\eta^{2}\right.$-dppm)][PF 6 ruthenium complexes with $\mathrm{C}_{2} \mathrm{O}_{4}\left(\mathrm{Me}_{4} \mathrm{~N}\right)_{2}$ in the mol ratios 1:1 and 2:1. While the $2: 1$ ratio reaction led to the sole and expected binuclear product $\left\{\left[\operatorname{Ru}\left(\eta^{6}-p-c y m e n e\right)\left(\eta^{2}-\operatorname{dppm}\right)\right]_{2}\left(\mu-\eta^{2}-\right.\right.$ $\left.\left.\mathrm{C}_{2} \mathrm{O}_{4}\right)\right\}\left[\mathrm{PF}_{6}\right]_{2}$, the reaction also afforded the unexpected mononuclear complex $\left[\mathrm{RuCl}\left(\eta^{2}-\mathrm{C}_{2} \mathrm{O}_{4}\right)\left(\eta^{6}-p-\right.\right.$ cymene) $]\left[\mathrm{Me}_{4} \mathrm{~N}\right]$. This can also be obtained in improved yield by reacting $\left[\mathrm{RuCl}_{2}(p \text {-cymene) }]_{2}\right.$ with $\mathrm{C}_{2} \mathrm{O}_{4}\left[\mathrm{Me}_{4} \mathrm{~N}\right]_{2}$ in a $1: 1 \mathrm{~mol}$ ratio. Surprisingly, when $\left[\mathrm{RuCl}\left(\eta^{6}-p \text {-cymene }\right)\right]_{2}\left(\mu-\eta^{4}-\mathrm{C}_{2} \mathrm{O}_{4}\right)$ was reacted with an equimolar amount of the ligand dppm, the expected complex $\left\{\left[\mathrm{Ru}\left(\eta^{6}-p \text {-cymene }\right)\right]_{2}\left(\mu-\eta^{4}-\mathrm{C}_{2} \mathrm{O}_{4}\right)(\mu-\mathrm{dppm})\right\}\left[\mathrm{PF}_{6}\right]_{2}$ was accompanied by $\left[\operatorname{RuCl}\left(\eta^{6}-p\right.\right.$-cymene $\left.)\left(\eta^{2}-\mathrm{dppm}\right)\right]\left[\mathrm{PF}_{6}\right]$ in an inseparable solid mixture.
\end{abstract}

KEY WORDS: Ruthenium, Arene, $p$-cymene, Mesitylene, Oxalate, bis-(Dipenylphosphino)methane

\section{INTRODUCTION}

In earlier publications, we have reported on the reactivity of $\left[\operatorname{RuCl}_{2}\left(\eta^{6} \text {-arene) }\right]_{2} \mathbf{1}\right.$ (arene $=p$ cymene 1a and mesitylene 1b) complexes toward bis-(diphenylphosphino)methane (dppm) [1, 2] and tetramethylammonium oxalate $\left(\mathrm{C}_{2} \mathrm{O}_{4} \mathrm{TMN}_{2}, \mathrm{TMN}=\left(\mathrm{CH}_{3}\right)_{4} \mathrm{~N}^{+}\right)$[2]. Recent reports on the synthesis [3] and the reactivity [3, 4] of $\left[\mathrm{RuCl}\left(\eta^{6}-p \text {-cymene }\right)\right]_{2}\left(\mu-\eta^{4}-\mathrm{C}_{2} \mathrm{O}_{4}\right) 2$ prompted us to reinvestigate our initial studies in this field.

The chemistry of dimers $\left[\mathrm{RuCl}_{2}\left(\eta^{6} \text {-arene }\right)\right]_{2}$ is centred around the cleavage of the bridging chloro ligands and the heterolytic rupture, under the effect of a polar solvent, of one of the two $\mathrm{Ru}-\mathrm{Cl}$ bonds [5]. Furthermore, the advantage of the facile coordination of numerous varieties of electron donor pair ligands to the metal centre offers useful methods of access to an increasing range of mono-, bi- and polynuclear ( $\eta^{6}$-arene) ruthenium(II) complexes [6].

Since the discovery of such reactivity, the chemistry of arene ruthenium derivatives has shown remarkable development in the homogeneous catalysis [7]. Arene ruthenium complexes have proved to be very active for olefin metathesis [8], Diels-Alder activation [9], catalytic hydrogenation of ketones [10], etc. Furthermore, these complexes have recently demonstrated efficient anticancer, antibacterial and antiviral activities, and some complexes are currently making significant progress in clinical trials [11]. In particular, arene ruthenium oxalato complexes are remarkable in cancer chemotherapy and a number of them have exhibited effectiveness in inhibiting cancer cell-growth proliferation [12].

The present paper deals with the reaction of $\left[\mathrm{RuCl}\left(\eta^{6}-p \text {-cymene }\right)\right]_{2}\left(\mu-\eta^{4}-\mathrm{C}_{2} \mathrm{O}_{4}\right)$ and $\left[\mathrm{RuCl}\left(\eta^{6}-\right.\right.$ $p$-cymene $)\left(\eta^{2}\right.$-dppm) $]\left[\mathrm{PF}_{6}\right]$ complexes with oxalato and dppm ligands.

*Corresponding author. E-mail: falloumb@refer.sn 


\section{EXPERIMENTAL}

All synthetic reactions were carried out under nitrogen using standard Schlenk techniques. Organic solvents were distilled by conventional practices, kept to dryness over drying agents under nitrogen and degassed before use. NMR spectra were recorded on a Bruker AM300 spectrometer taking TMS as reference. Infrared spectra were determined on a Jasco FT/IR-5300 (Nujol mulls) and on Nicolet $250(\mathrm{KBr})$ instruments. Microanalytical data were determined by the Service de Microanalyse du CNRS (Vernaison/France). Dimers $\left[\mathrm{RuCl}_{2}\left(\eta^{6}-p \text {-cymene) }\right]_{2}(\mathbf{1 a})\right.$ [13] and $\left[\mathrm{RuCl}_{2}\left(\eta^{6} \text {-mesitylene }\right)\right]_{2}(\mathbf{1 b})$ [14] were prepared according to published methods from the starting material $\mathrm{RuCl}_{3} \cdot 3 \mathrm{H}_{2} \mathrm{O}$ purchased from Aldrich. Dppm was also obtained from Aldrich. Tetramethylammonium oxalate was a gift from Laboratoire de Chimie Minérale et Analytique (UCAD/Sénégal) prior to being synthesized by ourselves. $\left[\operatorname{RuCl}\left(\eta^{6}-p\right.\right.$-cymene $)\left(\eta^{2}-\right.$ dppm) $]\left[\mathrm{PF}_{6}\right](\mathbf{9})$ was synthesized as reported by us [1].

[RuCl( $\eta^{6}$-p-cymene $\left.)\right]_{2}\left(\mu-\eta^{4}-C_{2} O_{4}\right)$ (2). A solution of $\mathrm{C}_{2} \mathrm{O}_{4} \mathrm{TMN}_{2}(0.193 \mathrm{~g}, 0.817 \mathrm{mmol})$ in $\mathrm{MeOH}(10 \mathrm{~mL})$ was added to a red brown solution of $\left[\mathrm{RuCl}_{2}\left(\eta^{6}-p \text {-cymene }\right)\right]_{2}(0.500 \mathrm{~g}, 0.817$ $\mathrm{mmol})$ in $\mathrm{CH}_{2} \mathrm{Cl}_{2}(10 \mathrm{~mL})$. The reaction mixture was then stirred upon completion for $24 \mathrm{~h}$ at room temperature under $\mathrm{N}_{2}$. The resulting yellow solution was then evaporated to dryness under reduced pressure. Thereafter, the so obtained residue was taken up in $\mathrm{CH}_{2} \mathrm{Cl}_{2}(20 \mathrm{~mL})$ and the resulting slurry filtered in air and on celite to remove the $\mathrm{TMNCl}$ salt. The orange filtrate collected was afterwards evaporated under vacuum to give an air stable solid in a yellow powdered form. The product was then recrystallized in a freeze by slow vapour diffusion of hexane in a saturated solution of the solid in $\mathrm{CH}_{2} \mathrm{Cl}_{2}$. After removing the solvent and drying the solid, compound 2 was gathered as yellow crystals. Yield: $0.500 \mathrm{~g}, 97 \%$. Analysis (\%): found (calculated for $\mathrm{C}_{22} \mathrm{H}_{28} \mathrm{Cl}_{2} \mathrm{O}_{4} \mathrm{Ru}_{2}, 629.14 \mathrm{~g} / \mathrm{mol}$ ): $\mathrm{C} 41.83$ (41.96), $\mathrm{H} 4.98$ (4.45). IR (Nujol) $\mathrm{cm}^{-1}$ : $1616\left(v_{\text {as }(\mathrm{OCO})}\right) ;(\mathrm{KBr}) \mathrm{cm}^{-1}: 1615\left(v_{\mathrm{as}(\mathrm{OCO})}\right), 1375\left(v_{\mathrm{s}(\mathrm{OCO})}\right) . \mathrm{NMR}{ }^{1} \mathrm{H}\left[\left(\mathrm{CD}_{3}\right)_{2} \mathrm{CO}, 300.135 \mathrm{MHz}\right.$, $297 \mathrm{~K}] \delta(\mathrm{ppm}): 5.7,5.4\left(\mathrm{dd}, 4 \mathrm{H}, \mathrm{J}_{\mathrm{HH}}=6.07 \mathrm{~Hz}, \mathrm{Me}-\mathrm{C}_{6} \underline{\mathrm{H}}_{4}{ }^{i} \mathrm{Pr}\right), 2.3\left(\mathrm{~m}, 1 \mathrm{H}, \mathrm{J}_{\mathrm{HH}}=6.90 \mathrm{~Hz}\right.$, $\left.\mathrm{Me}_{-} \mathrm{C}_{6} \mathrm{H}_{4}-\underline{\mathrm{CHMe}}_{2}\right), 2.2\left(\mathrm{~s}, 3 \mathrm{H}, \mathrm{CH}_{3}-\mathrm{C}_{6} \mathrm{H}_{4}{ }^{i} \mathrm{Pr}\right), 1.8\left(\mathrm{~m}, 1 \mathrm{H}, \mathrm{J}_{\mathrm{HH}}=6.91 \mathrm{~Hz}, \mathrm{Me}-\mathrm{C}_{6} \mathrm{H}_{4}-\mathrm{C}^{\mathrm{H}} \mathrm{Je}_{2}\right), 1.3$ $\left(\mathrm{d}, 6 \mathrm{H}, \mathrm{J}_{\mathrm{HH}}=6.93 \mathrm{~Hz}, \mathrm{Me}-\mathrm{C}_{6} \mathrm{H}_{4}-\mathrm{CH}\left(\mathrm{CH}_{3}\right)_{2}\right)$.

$\left[R u C l\left(\eta^{6} \text {-mesitylene }\right)\right]_{2}\left(\mu-\eta^{4}-C_{2} O_{4}\right)(\mathbf{3}, \mathbf{4})$. When a solution of $\mathrm{C}_{2} \mathrm{O}_{4} \mathrm{TMN}_{2}(0.404 \mathrm{~g}, 1.712 \mathrm{mmol})$ in $\mathrm{MeOH}(10 \mathrm{~mL})$ was added to a brown solution of $\left[\mathrm{RuCl}_{2}\left(\eta^{6} \text {-mesitylene }\right)\right]_{2}(1 \mathrm{~g}, 1.712 \mathrm{mmol})$ in $\mathrm{CH}_{2} \mathrm{Cl}_{2}(10 \mathrm{~mL})$, at room temperature and under nitrogen, a pale green solid identified to complex 3 suddenly precipitated. The stirring was nevertheless maintained for 4 hours. The precipitate was then filtered off, washed with diethyl ether and dried under vacuum. Complex 3 was obtained in a pale green solid state insoluble in most organic solvents. Yield: $675 \mathrm{mg}, 67 \%$. Analysis (\%): found (calculated for $\mathrm{C}_{20} \mathrm{H}_{24} \mathrm{Cl}_{2} \mathrm{O}_{4} \mathrm{Ru}_{2}: 603.14 \mathrm{~g} / \mathrm{mol}$ or for $\mathrm{C}_{40} \mathrm{H}_{48} \mathrm{Cl}_{4} \mathrm{O}_{8} \mathrm{Ru}_{4}$ : $1206.28 \mathrm{~g} / \mathrm{mol}$ ): C 39.41 (39.79), H 3.90 (3.98). IR (in Nujol mulls) $\mathrm{cm}^{-1}: 1620$ ( $v_{\mathrm{as}(\mathrm{OCO})}$ ). The filtrate was thereafter evaporated to dryness and the solid mixture melted in $\mathrm{CH}_{2} \mathrm{Cl}_{2}(20 \mathrm{~mL})$. Thus, complex 4 was isolated (yield: $0.011 \mathrm{~g}, 14 \%$ ) in the form of a yellow solid after work up as mentioned above for the isolation of compound 2. Analysis (\%): found (calculated for $\mathrm{C}_{20} \mathrm{H}_{24} \mathrm{Cl}_{2} \mathrm{O}_{4} \mathrm{Ru}_{2}, 603.14 \mathrm{~g} / \mathrm{mol}$ ): C 39.53 (39.79), H 3.75 (3.98). IR (in Nujol mulls) cm ${ }^{-1}: 1624$ $\left(\mathrm{v}_{\mathrm{as}(\mathrm{OCO})}\right)$; (in $\left.\mathrm{KBr} \operatorname{disc}\right) \mathrm{cm}^{-1}: 1618\left(\mathrm{v}_{\mathrm{as}(\mathrm{OCO})}\right), 1384\left(\mathrm{v}_{\mathrm{as}(\mathrm{OCO})}\right) . \mathrm{NMR}{ }^{1} \mathrm{H}\left[\left(\mathrm{CD}_{3}\right)_{2} \mathrm{CO} ; 300.135 \mathrm{MHz}\right.$; $297 \mathrm{~K}] \delta(\mathrm{ppm}): 5.2\left(\mathrm{~s}, 3 \mathrm{H}, \mathrm{C}_{6} \underline{\mathrm{H}}_{3}\right), 2.2\left(\mathrm{~s}, 9 \mathrm{H},-\underline{\mathrm{C}}_{3}\right)$.

$\left[\mathrm{RuCl}\left(\eta^{2}-\mathrm{C}_{2} \mathrm{O}_{4}\right)\left(\eta^{6}\right.\right.$-p-cymene $\left.)\right] T M N$ (7). Two procedures were used for the preparation of complex 7. Procedure A. The ligand $\mathrm{C}_{2} \mathrm{O}_{4} \mathrm{TMN}_{2}(0.075 \mathrm{~g}, 0.305 \mathrm{mmol})$ in solution in $\mathrm{MeOH}$ $(10 \mathrm{~mL})$ was added dropwise to a stirred solution of $2(0.200 \mathrm{~g}, 0.305 \mathrm{mmol})$ in $\mathrm{CH}_{2} \mathrm{Cl}_{2}(10 \mathrm{~mL})$ at room temperature under $\mathrm{N}_{2}$. After $72 \mathrm{~h}$ of stirring, the solvents were removed under vacuum. The crude residue was subsequently extracted with $\mathrm{CH}_{2} \mathrm{Cl}_{2}(20 \mathrm{~mL})$ and the extract filtered in air 
and on celite. The evaporation of the filtrate gave a pale yellow solid that was purified as above and identified later to complex 7. Yield: $0.044 \mathrm{~g}, 17 \%$. Analysis (\%): found (calculated for $\mathrm{C}_{16} \mathrm{H}_{26} \mathrm{NClO}_{4} \mathrm{Ru} . \mathrm{H}_{2} \mathrm{O}, 450.57 \mathrm{~g} / \mathrm{mol}$ ): C 42.39 (42.61), H 6.10 (6.21). IR (Nujol) cm $\mathrm{cm}^{-1}: 1701$ $\left(v_{(\mathrm{C}=\mathrm{O})}\right), 1657,1635\left(v_{\mathrm{as}(\mathrm{OCO})}\right), 951\left(v_{(\mathrm{NC} 4)}\right) .{ }^{1} \mathrm{H} \mathrm{NMR}\left[\left(\mathrm{CD}_{3}\right)_{2} \mathrm{CO}, 300.135 \mathrm{MHz}, 297 \mathrm{~K}\right] \delta(\mathrm{ppm})$ : $5.45,5.15\left(\mathrm{dd}, 4 \mathrm{H}, \mathrm{J}_{\mathrm{HH}}=5.97 \mathrm{~Hz}, \mathrm{Me}-\mathrm{C}_{6} \underline{\mathrm{H}}_{4}{ }^{i} \mathrm{Pr}\right), 3.4\left(\mathrm{~s},\left(\mathrm{CH}_{3}\right)_{2} \mathrm{~N}^{+}\right), 2.25\left(\mathrm{~m}, 1 \mathrm{H}, \mathrm{Me}-\mathrm{C}_{6} \mathrm{H}_{4}-\right.$ $\left.\mathrm{C} \mathrm{HMe}_{2}\right), 2.15\left(\mathrm{~s}, 3 \mathrm{H}, \mathrm{C}_{3}-\mathrm{C}_{6} \mathrm{H}_{4}{ }^{i} \mathrm{Pr}\right), 1.85\left(\mathrm{~m}, 1 \mathrm{H}, \mathrm{J}_{\mathrm{HH}}=6.91 \mathrm{~Hz}, \mathrm{Me}-\mathrm{C}_{6} \mathrm{H}_{4}-\mathrm{CHMe}_{2}\right), 1.34(\mathrm{~d}$, $\left.6 \overline{\mathrm{H}}, \mathrm{J}_{\mathrm{HH}}=6.93 \mathrm{~Hz}, \mathrm{Me}-\overline{\mathrm{C}}_{6} \mathrm{H}_{4}-\mathrm{CH}\left(\mathrm{CH}_{3}\right)_{2}\right) .{ }^{13} \mathrm{C} \mathrm{NMR}\left[\left(\mathrm{CD}_{3}\right)_{2} \mathrm{CO}, 75.034 \mathrm{MHz}, 297 \mathrm{~K}\right] \delta(\mathrm{ppm})$ : 207, 42 (s, C=O). Procedure B. Complex 7 was obtained in form of a yellow and air stable solid (yield: $0.040 \mathrm{~g}, 57 \%)$ according to the described procedure for 2 by reacting $\left[\mathrm{RuCl}_{2}\left(\eta^{6}-p\right.\right.$ cymene $)]_{2}(0.100 \mathrm{~g}, 0.165 \mathrm{mmol})$ with a large excess of $\mathrm{C}_{2} \mathrm{O}_{4} \mathrm{TMN}_{2}(0.100 \mathrm{~g}, 0.423 \mathrm{mmol})$, with respect to the mol ratio 1:2. Analysis (\%): found (calculated for $\mathrm{C}_{16} \mathrm{H}_{26} \mathrm{NClO}_{4} \mathrm{Ru}, 432.57 \mathrm{~g} / \mathrm{mol}$ ): C 42.66 (42.61), H 6.52 (6.21). IR (Nujol) $\mathrm{cm}^{-1}: 1700\left(v_{(\mathrm{C}=\mathrm{O})}\right), 1658,1635\left(v_{\mathrm{as}(\mathrm{OCO})}\right), 951\left(v_{(\mathrm{NC} 4)}\right)$. $\mathrm{NMR}{ }^{1} \mathrm{H}\left[\left(\mathrm{CD}_{3}\right)_{2} \mathrm{CO}, 300.135 \mathrm{MHz}, 297 \mathrm{~K}\right] \delta(\mathrm{ppm}): 5.45,5.15\left(\mathrm{dd}, 4 \mathrm{H}, \mathrm{J}_{\mathrm{HH}}=5.80 \mathrm{~Hz}, \mathrm{Me}-\right.$ $\left.\mathrm{C}_{6} \underline{\mathrm{H}}_{4}{ }^{i} \mathrm{Pr}\right), 3.40\left(\mathrm{~s},\left(\mathrm{CH}_{3}\right)_{2} \mathrm{~N}^{+}\right), 2.30\left(\mathrm{~m}, 1 \mathrm{H}, \mathrm{J}_{\mathrm{HH}}=6.89 \mathrm{~Hz}, \mathrm{Me}-\mathrm{C}_{6} \mathrm{H}_{4}-\mathrm{CHMe}_{2}\right), 2.20\left(\mathrm{~s}, 3 \mathrm{H}, \mathrm{C}_{\mathrm{H}_{3}}-\right.$ $\left.\mathrm{C}_{6} \mathrm{H}_{4}{ }^{i} \mathrm{Pr}\right), 1.80\left(\mathrm{~m}, 1 \mathrm{H}, \mathrm{J}_{\mathrm{HH}}=6.91 \mathrm{~Hz}, \mathrm{Me}^{\mathrm{C}} \mathrm{C}_{6} \mathrm{H}_{4}-\mathrm{CHMe}_{2}\right), 1.30\left(\mathrm{~d}, 6 \mathrm{H}, \mathrm{J}_{\mathrm{HH}}=6.93 \mathrm{~Hz}, \mathrm{Me}-\right.$ $\left.\mathrm{C}_{6} \mathrm{H}_{4}-\mathrm{CH}\left(\mathrm{CH}_{3}\right)_{2}\right)$.

$\left.\left[R u\left(\eta^{6}-p \text {-cymene }\right)\right]_{2}\left(\mu-\eta^{4}-C_{2} O_{4}\right)(\mu-d p p m)\right]\left[P_{6}\right]_{2}(\mathbf{8})$ and $\left[R u C l\left(\eta^{6}-p-c y m e n e\right)\left(\eta^{2}-d p p m\right)\right]\left[P F_{6}\right]$ (9). A stirred solution of complex $2(0.100 \mathrm{~g}, 0.160 \mathrm{mmol})$ and the ligand dppm $(0.063 \mathrm{~g}, 0.160$ $\mathrm{mmol})$, in a mixture of $\mathrm{MeOH}(10 \mathrm{~mL})$ and $\mathrm{CH}_{2} \mathrm{Cl}_{2}(10 \mathrm{~mL})$, was treated dropwise with $\mathrm{NH}_{4} \mathrm{PF}_{6}$ $(0.052 \mathrm{~g}, 0.320 \mathrm{mmol})$ at room temperature under $\mathrm{N}_{2}$. The resultant yellow solution gradually turned to brown during stirring. After $72 \mathrm{~h}$, the solvents were evaporated to dryness under vacuum. Thus, the solid material was dissolved in $\mathrm{CH}_{2} \mathrm{Cl}_{2}(20 \mathrm{~mL})$. The brown supernatant liquid was next filtered off on celite and evaporated to dryness under reduced pressure. By this means, the obtained brown solid was washed twice with $10 \mathrm{~mL}$ portions of diethyl ether. Drying as well as purification led to a brown powder that will be recognized to be a mixture on the whole percentage of $44.5 \%$ of complex 8 and $55.5 \%$ of complex 9. Analysis (\%): found (calculated for a mixture of $44.5 \%$ of $\mathrm{C}_{47} \mathrm{H}_{50} \mathrm{P}_{4} \mathrm{~F}_{12} \mathrm{O}_{4} \mathrm{Ru}_{2}$ (8) and $54.5 \%$ of $\mathrm{C}_{35} \mathrm{H}_{36} \mathrm{P}_{3} \mathrm{~F}_{6} \mathrm{ClRu} .3 \mathrm{H}_{2} \mathrm{O}$ (9)): $\mathrm{C} 46.53$ (46.29), $\mathrm{H} 4.43$ (4.61), P 9.18 (9.85). IR (Nujol) $\mathrm{cm}^{-1}$ : $1680,1660,1624\left(v_{\mathrm{as}(\mathrm{OCO})}\right), 839\left(\mathrm{v}_{\mathrm{PF}}\right) . \mathrm{NMR}{ }^{31} \mathrm{P}\left\{{ }^{1} \mathrm{H}\right\}\left[\left(\mathrm{CD}_{3}\right)_{2} \mathrm{CO}, 121.497 \mathrm{MHz}, 297 \mathrm{~K}\right] \delta$ (ppm): $25.86\left(\mathrm{~s}, \mu-\mathrm{PCH}_{2} \mathrm{P}\right.$ of (8)), $3.23\left(\mathrm{~s}, \eta^{2}-\mathrm{PCH}_{2} \mathrm{P}\right.$ of $\left.(9)\right),-143,04\left(\mathrm{~m}, \mathrm{PF}_{6}{ }^{-}\right) . \mathrm{NMR}{ }^{1} \mathrm{H}$ $\left[\left(\mathrm{CD}_{3}\right)_{2} \mathrm{CO}, 300.135 \mathrm{MHz}, 297 \mathrm{~K}\right] \delta(\mathrm{ppm}): 7.5-7.9\left(\mathrm{~m}, \mathrm{C}_{6} \underline{\mathrm{H}}_{5}\right), 6.6,6.5\left(\mathrm{dd}, \mathrm{Me}-\mathrm{C}_{6} \underline{\mathrm{H}}_{4}{ }^{i} \mathrm{Pr}\right.$ of $\left.(\mathbf{9})\right)$, 5.7, $5.45\left(\left(\mathrm{dd}, \mathrm{Me}_{-} \mathrm{C}_{6} \underline{\mathrm{H}}_{4}{ }^{i} \mathrm{Pr}\right.\right.$ of $\left.(\mathbf{8})\right), 5.60\left(\left(\mathrm{dt}, \mathrm{PCH}_{2} \mathrm{P}\right.\right.$ of $\left.(\mathbf{9})\right), 4.7\left(\mathrm{dt}, \mathrm{PC}_{\mathrm{H}_{2}} \mathrm{P}\right.$ of $\left.(\mathbf{9})\right), 4.3$ (t, $\mathrm{PC}_{2} \mathrm{P}$ of (8)), 2.4 (m, 1H, Me- $\mathrm{C}_{6} \mathrm{H}_{4}-\mathrm{CHMe}_{2}$ of (9)), 2.3 (m, 1H, Me- $\mathrm{C}_{6} \mathrm{H}_{4}-\mathrm{C}^{-} \mathrm{He}_{2}$ of (8)), 1.9 (s, $3 \mathrm{H}, \mathrm{CH}_{3}-\mathrm{C}_{6} \mathrm{H}_{4}{ }^{i} \mathrm{Pr}$ of (9)), 1.55 (s, $3 \mathrm{H}, \mathrm{C}_{3}-\mathrm{C}_{6} \mathrm{H}_{4}{ }^{i} \mathrm{Pr}$ of $\left.(\mathbf{8})\right), 1.25\left(\mathrm{~d}, 6 \mathrm{H}, \mathrm{Me}-\mathrm{C}_{6} \mathrm{H}_{4}-\mathrm{CH}\left(\mathrm{C}_{3}\right)_{2}\right.$ of (9)), 1.15 (d, 6H, Me- $\mathrm{C}_{6} \mathrm{H}_{4}-\mathrm{CH}\left(\mathrm{C}_{3}\right)_{2}$ of $\left.(\mathbf{8})\right)$.

$\left\{\left[R u\left(\eta^{6}-p \text {-cymene }\right)\left(\eta^{2}-d p p m\right)\right]_{2} \cdot\left(\mu-\eta^{2}-C_{2} O_{4}\right)\right\}\left[P F_{6}\right]_{2}(\mathbf{1 0})$. A solution of $9(0.100 \mathrm{~g}, 0.125 \mathrm{mmol})$ and $\mathrm{C}_{2} \mathrm{O}_{4} \mathrm{TMN}_{2}(0.015 \mathrm{~g}, 62.5 \mathrm{mmol})$, in a mixture of $\mathrm{MeOH}(10 \mathrm{~mL})$ and $\mathrm{CH}_{2} \mathrm{Cl}_{2}(10 \mathrm{~mL})$, was stirred for $72 \mathrm{~h}$. After removal of the solvents, the yellow powdered solid was melted in $\mathrm{CH}_{2} \mathrm{Cl}_{2}$ $(20 \mathrm{~mL})$. After that, the resulting solution was filtered off to remove the salt $\mathrm{NH}_{4} \mathrm{Cl}$ and the filtrate evaporated to dryness. Next, the product was washed twice with small portions of diethyl ether. Drying yielded complex (10) in a yellow solid form exclusive of further purification. Yield: $0.084 \mathrm{~g}, 49 \%$. Analysis (\%): found (calculated for $\mathrm{C}_{72} \mathrm{H}_{72} \mathrm{P}_{6} \mathrm{~F}_{12} \mathrm{O}_{4} \mathrm{Ru}_{2}, 1616.14 \mathrm{~g} / \mathrm{mol}$ ): $\mathrm{C}$ 53.78 (53.46), H 4.86 (4.63). IR (Nujol) $\mathrm{cm}^{-1}: 1700.00\left(v_{(\mathrm{C}=0)}\right), 1651,1625\left(v_{\mathrm{as}(\mathrm{OCO})}\right), 839\left(v_{\mathrm{PF}}\right)$. $\mathrm{NMR}{ }^{31} \mathrm{P}\left\{{ }^{1} \mathrm{H}\right\}\left[\left(\mathrm{CD}_{3}\right)_{2} \mathrm{CO}, 121.497 \mathrm{MHz}, 297 \mathrm{~K}\right] \delta(\mathrm{ppm}): 3.96\left(\mathrm{~s}, \eta^{2}-\mathrm{PCH}_{2} \mathrm{P}\right),-143.04(\mathrm{~m}$, $\left.\mathrm{PF}_{6}{ }^{-}\right) . \mathrm{NMR}{ }^{1} \mathrm{H}\left[\left(\mathrm{CD}_{3}\right)_{2} \mathrm{CO}, 300.135 \mathrm{MHz}, 297 \mathrm{~K}\right] \delta(\mathrm{ppm}): 7.9-7.5\left(\mathrm{~m},-\mathrm{C}_{6} \mathrm{H}_{5}\right), 6.6,6.5(\mathrm{~d}, 4 \mathrm{H}$, $\left.\mathrm{Me}-\mathrm{C}_{6} \underline{\mathrm{H}}_{4}{ }^{i} \mathrm{Pr}\right) ; 5.8\left(\mathrm{~m}, 2 \mathrm{H}, \mathrm{PCH}_{2} \mathrm{P}\right), 4.6\left(\mathrm{~m}, 2 \mathrm{H}, \mathrm{PC}_{2} \mathrm{P}\right), 2.5\left(\mathrm{~m}, 1 \mathrm{H}, \mathrm{Me}-\mathrm{C}_{6} \mathrm{H}_{4}-\mathrm{CHMe}_{2}\right), 1.5$ (s, $\left.3 \mathrm{H}, \underline{\mathrm{C}}_{3}-\mathrm{C}_{6} \mathrm{H}_{4}-\mathrm{Pr}\right), 1.15$ (d, $\left.6 \mathrm{H}, \mathrm{Me}-\mathrm{C}_{6} \mathrm{H}_{4}-\mathrm{CH}\left(\mathrm{C}_{3}\right)_{2}\right)$. 


\section{RESULTS AND DISCUSSION}

The preparation of $\left[\mathrm{RuCl}\left(\eta^{6}-p \text {-cymene }\right)\right]_{2}\left(\mu-\eta^{4}-\mathrm{C}_{2} \mathrm{O}_{4}\right) 2$ was first reported by Yan and coworkers [3]. Four years earlier, as mentioned in that study, we had reacted the oxalato ligand with $\left[\mathrm{RuCl}_{2}\left(\eta^{6} \text {-arene) }\right]_{2}\right.$ (arene $=p$-cymene 1a, and mesitylene 1b). In contrast to the later procedures $[3,4]$, we used $\mathrm{C}_{2} \mathrm{O}_{4}(\mathrm{TMN})_{2}$ instead of the commercially available ammonium and sodium oxalate salts. Our choice of reagent was determined by two factors. Firstly, we tried to prevent a possible acidification by the ammonium salt, by employing $\mathrm{C}_{2} \mathrm{O}_{4}\left(\mathrm{NH}_{4}\right)_{2}$, and, secondly, the organometallic complexes are water-sensitive.

The oxalato ligand has long played an important role in coordination chemistry [15]. It is easily isolated in the form of a white hygroscopic solid by acid-base neutralization of oxalic acid $\left(\mathrm{H}_{2} \mathrm{C}_{2} \mathrm{O}_{4}\right)$ with the tetramethylammonium hydroxide (TMNOH) in absolute ethanol [16].

Once bonded to the $\mathrm{Ru}(\mathrm{II})$, the characterization of the oxalato ligand by infrared spectroscopy (IR) is possible and gives information on its mode of coordination by use of group theory calculations [17].

$\left[\mathrm{RuCl}\left(\eta^{6} \text {-arene }\right)\right]_{2} \cdot\left(\mu-\eta^{4}-\mathrm{C}_{2} \mathrm{O}_{4}\right)$ complexes (arene $=$-cymene and mesitylene $)(\mathbf{2}-\mathbf{4})$

As depicted in Figure 1, 1a was reacted with $\mathrm{C}_{2} \mathrm{O}_{4} \mathrm{TMN}_{2}$ in a mixture of $\mathrm{CH}_{2} \mathrm{Cl}_{2}-\mathrm{MeOH}$ in the mol ratio 1:1 (1 unit of the dimer per 1 unit of the ligand). The reaction led to a single yellow product 2 (97\% yield) soluble in $\mathrm{CH}_{2} \mathrm{Cl}_{2}$.

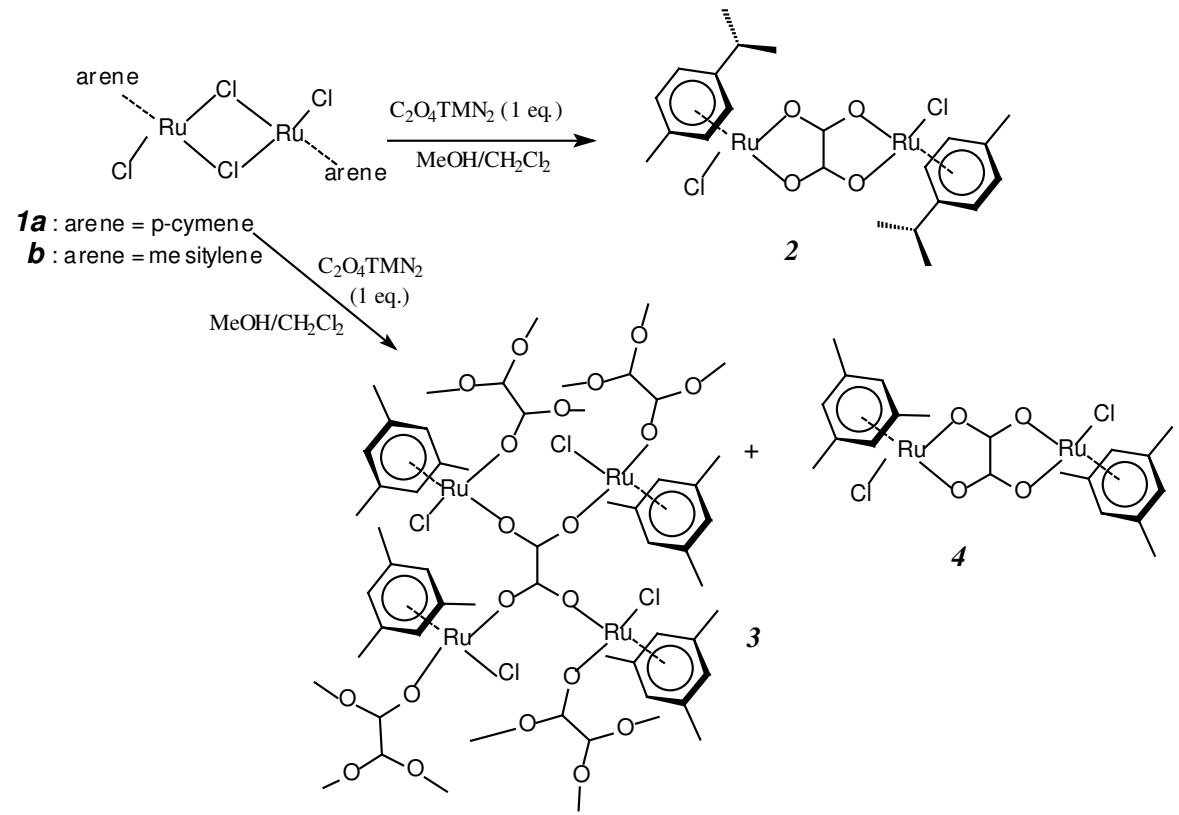

Figure 1. Scheme of formation of complexes (2-4).

Using identical reaction conditions, dimer $\mathbf{1 b}$ was reacted with $\mathrm{C}_{2} \mathrm{O}_{4}(\mathrm{TMN})_{2}$ yielding 3 (67 $\%$ yield) and $\mathbf{4}$ (14\% yield). Compound 3 was isolated in the form of a pale green precipitate insoluble in $\mathrm{CH}_{2} \mathrm{Cl}_{2}$ and other organic solvents, although slightly soluble in DMSO at room temperature. Complex 4 was obtained as a yellow solid soluble in $\mathrm{CH}_{2} \mathrm{Cl}_{2}$. 
Complexes $\mathbf{2}$ and $\mathbf{4}$ were characterized by infrared and ${ }^{1} \mathrm{H}$ NMR spectroscopy and $\mathbf{3}$ only by infrared spectroscopy. The IR spectra (Nujol mulls) shows a strong and unique band between 1646 and $1625 \mathrm{~cm}^{-1}$ associated with $v_{\mathrm{as}(\mathrm{OCO})}$. The infrared spectra of 2 and 4 in $\mathrm{KBr}$ show that the related $v_{\mathrm{s}(\mathrm{OCO})}$ band appears at 1375 and $1384 \mathrm{~cm}^{-1}$, while the $v_{\mathrm{as}(\mathrm{OCO})}$ band occurs at 1615 and $1618 \mathrm{~cm}^{-1}$ [18]. The absence of a third band above $1700 \mathrm{~cm}^{-1}$ is consistent with an identical perturbance of the four oxygen atoms corresponding to the $\mathrm{D}_{2} \mathrm{~h}$ symmetry group of the ligand.

As reported in the Experimental section, the presence of the arene groups is confirmed by ${ }^{1} \mathrm{H}$ NMR spectroscopy. For instance, the aromatic protons of the $p$-cymene group appear in two $\mathrm{AB}$ patterns at $\delta_{\mathrm{H}} 5.7$ and 5.4. Surprisingly, in the ${ }^{1} \mathrm{H}$ NMR spectrum of 2 , the isopropylic proton occurs as two multiplets at $\delta_{\mathrm{H}} 2.3\left(\mathrm{~J}_{\mathrm{HH}}=6.90 \mathrm{~Hz}\right)$ and $1.8\left(\mathrm{~J}_{\mathrm{HH}}=6.91 \mathrm{~Hz}\right)$, for an integration ratio of one proton. The ${ }^{1} \mathrm{H}$ NMR data of Yan and his co-workers [3] show only one peak at $\delta_{\mathrm{H}}$ 2.883 for the isopropylic proton. Accordingly, this study gave an account of the existence of two conformational isomers for complex $\mathbf{2}$, as well established by these authors for the complex of the identical analytical formula $\left[\operatorname{RuCl}\left(\eta^{6}-\mathrm{p} \text {-cymene }\right)\right]_{2} \cdot\left(\mu-\eta^{4}-\mathrm{C}_{2} \mathrm{O}_{4}\right)$ on the basis of a singlecrystal X-ray analysis [3]. The $\delta_{\text {Hisopropyl }}$ chemical shift $=1.8 \mathrm{ppm}$ could be due to a pronounced shielding effect of the chloro ligand (Figure 2).
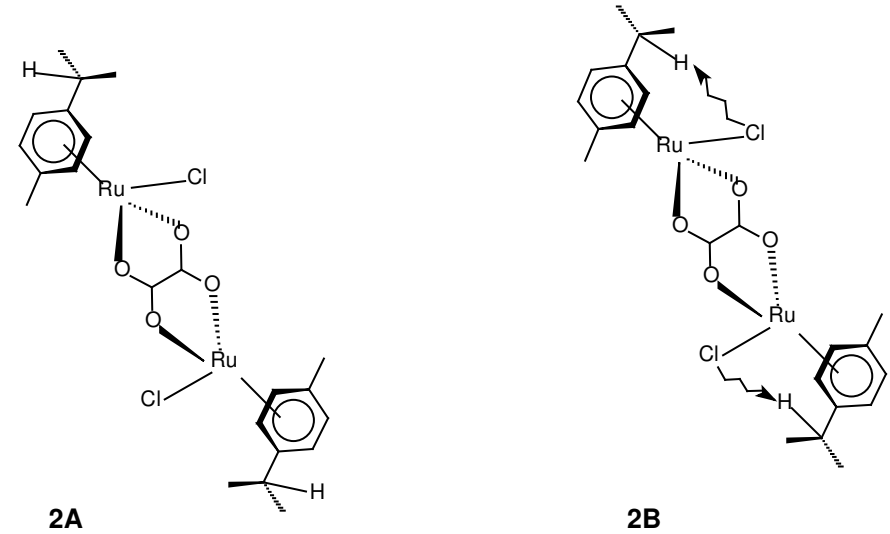

2B

Figure 2. Two conformational isomers for complex 2.

Similar observations in ${ }^{1} \mathrm{H}$ NMR spectra were reported by Bennett and Ennett for dinuclear $\left(\mu\right.$-hydrido)( $p$-cymene)Ru(II) complexes and Brunner et al. for chiral-at-metal $\left(\eta^{6}-p\right.$ cymene)Ru(II) and $\left(\eta^{6}-p\right.$-cymene)Os(II) half sandwich complexes [14]. In particular, Bennett and Ennett have found that both the $\mathrm{AB}$ patterns of the aromatic proton resonances and the isopropyl-methyl doublets of the $p$-cymene group are doubled in moving from species I to II (Figure 3).

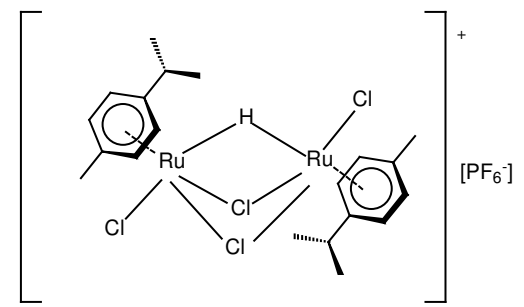

I

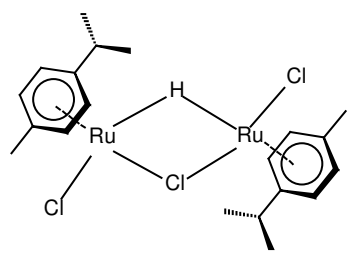

II

Figure 3. Species I and II.

Bull. Chem. Soc. Ethiop. 2008, 22(2) 
The reported elemental analysis, IR and ${ }^{1} \mathrm{H}$ NMR spectroscopies data for $\mathbf{4}$ are in agreement with an arene ruthenium oxalato complex of the formula $\left[\mathrm{RuCl}\left(\eta^{6} \text {-mesitylene }\right)\right]_{2}\left(\mu-\eta^{4}-\mathrm{C}_{2} \mathrm{O}_{4}\right)$. Complex 4 is then structurally analogous to 2 .

The infrared data of $\mathbf{3}$ are consistent with an oxalato ligand in the $\mathrm{D}_{2} \mathrm{~h}$ symmetry group. However, the additional microanalysis records and the insolubility of this compound are not sufficient to validate the proposed polymeric structure in Figure 1.

In a similar fashion, the difference in reactivity of dimers $p$-cymene and mesitylene ruthenium toward the oxalato ligand was also previously observed by Tocher and his co-workers when benzene and hexamethylbenzene ruthenium complexes were reacted with trifluoroacetic acid [19]. The reaction of trifluoroacetic acid, with $\left[\mathrm{RuCl}_{2}\left(\eta^{6} \text {-benzene }\right)\right]_{2}$ and $\left[\mathrm{RuCl}_{2}\left(\eta^{6}-\right.\right.$ hexamethylbenzene) $]_{2}$ dimers gave different products III and IV (Figure 4).

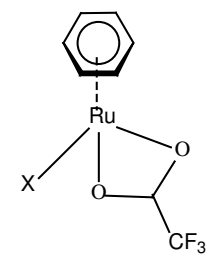

III

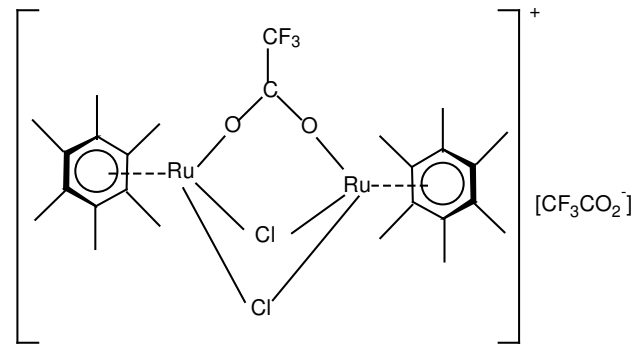

IV

Figure 4. Species III and IV.

The proposed structure 5 exhibits the same calculated analytical data (for $\mathrm{C}_{40} \mathrm{H}_{48} \mathrm{Cl}_{4} \mathrm{O}_{8} \mathrm{Ru}_{4}$ ) as that of $\mathbf{3}$ (for $\mathrm{C}_{20} \mathrm{H}_{24} \mathrm{Cl}_{2} \mathrm{O}_{4} \mathrm{Ru}_{2}$ ). Also, it is expected to show an infrared spectrum like that of 3. Since, in $\mathbf{5}$, the oxalate counter-cation is also in a $\mathrm{D}_{2} \mathrm{~h}$ symmetry group similar to $\mathrm{C}_{2} \mathrm{O}_{4}(\mathrm{TMN})_{2}$, its associated $v_{\mathrm{as}(\mathrm{OCO})}$ band and that of the bonded oxalate ligand could overlap. Thus, $\mathbf{5}$ would be the dimer of $\mathbf{3}$ (Figure 5).

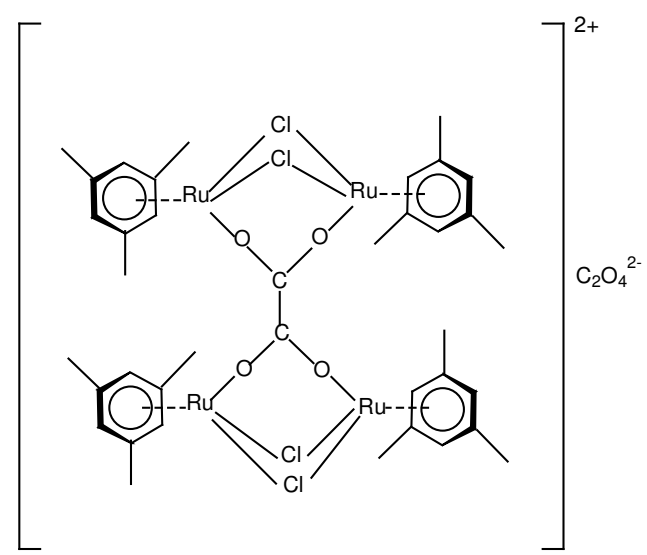

5

Figure 5. Complex $\mathbf{5}$ as a dimmer of $\mathbf{3}$.

Bull. Chem. Soc. Ethiop. 2008, 22(2) 
Complex $\left[\mathrm{RuCl}\left(\eta^{2}-\mathrm{C}_{2} \mathrm{O}_{4}\right)\left(\eta^{6}-\right.\right.$ - -cymene $\left.)\right][T M N](7)$

Compound 2 was reacted with an excess of $\mathrm{C}_{2} \mathrm{O}_{4} \mathrm{TMN}_{2}$, in a $\mathrm{CH}_{2} \mathrm{Cl}_{2}-\mathrm{MeOH}$ mixture, to give a red-brown solid 7 in a poor yield of $17 \%$ (Figure 6). The identification of the solid as 7 was established by elemental analysis and by infrared and NMR spectroscopies. The expected product $\mathbf{6}$ was not observed. The low yield of $\mathbf{7}$ is related to the decomposition of the reaction mixture over 3 days. The reaction was monitored with the aim of reducing its duration.

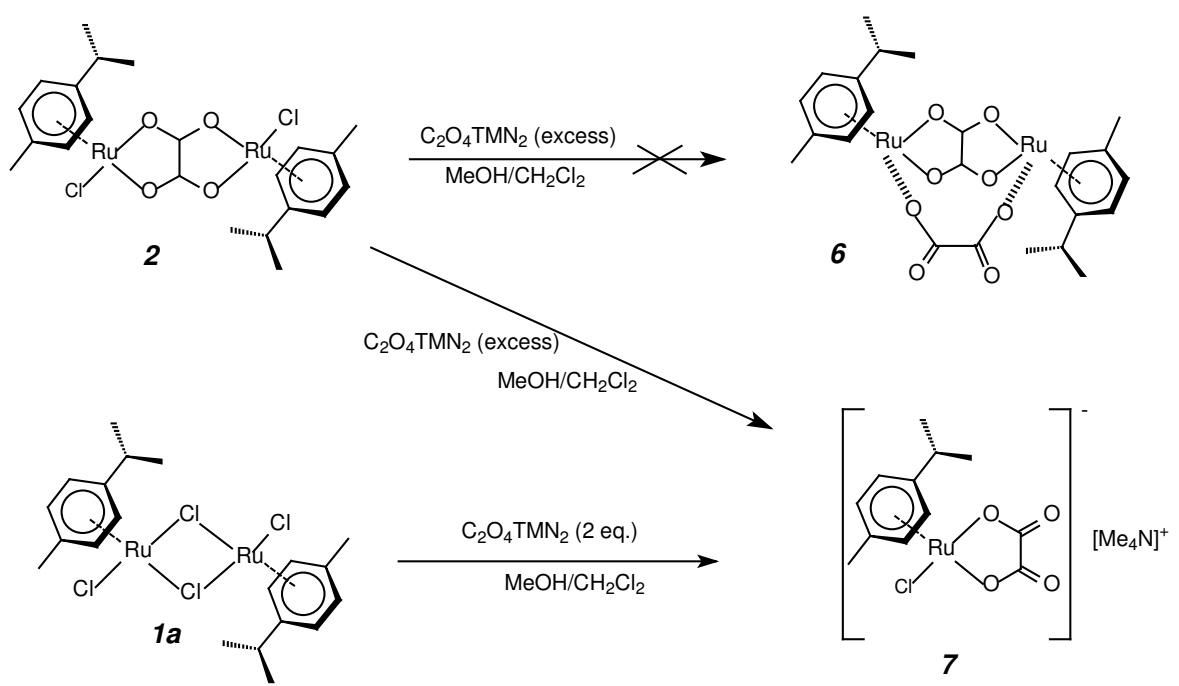

Figure 6. Scheme of formation of complexes (7).

An alternative route for the preparation of 7 consisted of treating $1 \mathrm{a}$ with $\mathrm{C}_{2} \mathrm{O}_{4} \mathrm{TMN}_{2}$ with a mol ratio 1:2 (1 equiv. of 1a per 2 equiv. of $\mathrm{C}_{2} \mathrm{O}_{4} \mathrm{TMN}_{2}$ ) at room temperature, in a mixture of $\mathrm{CH}_{2} \mathrm{Cl}_{2}$ and $\mathrm{MeOH}$. A red-brown solid 7 was obtained in a moderate yield of $57 \%$.

The infrared spectrum of 7 shows two bands at 1657 and $1635 \mathrm{~cm}^{-1}$ attributable to $v_{\text {as(OCO) }}$ stretching vibration. The additional shoulder at $1701 \mathrm{~cm}^{-1}$ is assigned to $v_{(\mathrm{C}=0)}$. Such IR bands are characteristic of an oxalate ligand in a $\mathrm{C}_{2} \mathrm{v}$ symmetry group. The presence of the countercation $\left.\mathrm{CH}_{3}\right)_{4} \mathrm{~N}^{+}$in the structure of 7 is confirmed by the band at $951 \mathrm{~cm}^{-1}$ assignable to the stretching vibration $v_{(\mathrm{NC} 4)}[20]$.

The ${ }^{1} \mathrm{H}$ NMR spectrum shows signals of the aromatic proton resonances at 5.45 and 5.15, similar to the ${ }^{1} \mathrm{H}$ NMR spectra of compound 2 . Resonances due to the methyl of the arene and those of the isopropyl group give two multiplets at 2.25 and 1.85 . This might reflect, as mentioned above, an interaction with the chloro group. The presence of the counter-anion $\left[\left(\mathrm{CH}_{3}\right)_{2} \mathrm{~N}\right]^{+}$is revealed by the peak at $3.40 \mathrm{ppm}$.

In connection with the crystal structures described by Yan and his co-workers [3], the reported spectroscopies and elemental analysis data are consistent with the existence of two conformational isomers 7A and 7B for complex 7 (Figure 7a). 


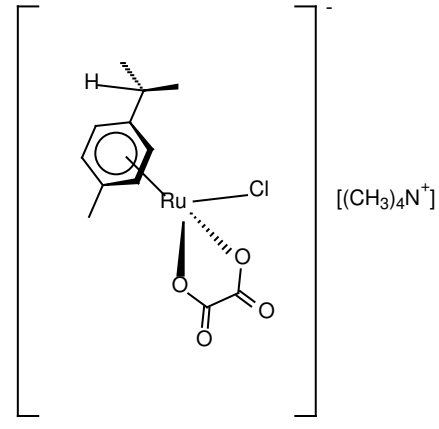

7A

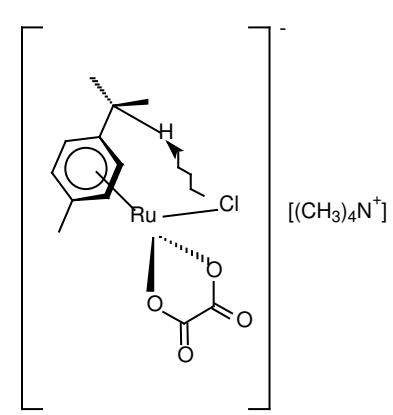

7B

Figure 7. Two conformational isomers of 7

Complex $\left.\left\{\left[R u\left(\eta^{6}-p-c y m e n e\right)\right]_{2} \cdot\left(\mu-\eta^{4}-C_{2} O_{4}\right)\right] \cdot(\mu-d p p m)\right\}\left[P F_{6}\right]_{2}(\mathbf{8}$ and $\mathbf{9})$

To elucidate the reactivity of $\mathbf{2}$ toward ligands, we determined whether dppm would replace the remaining chloride atoms or displace the oxalate ligand from the complex (Figure 8).
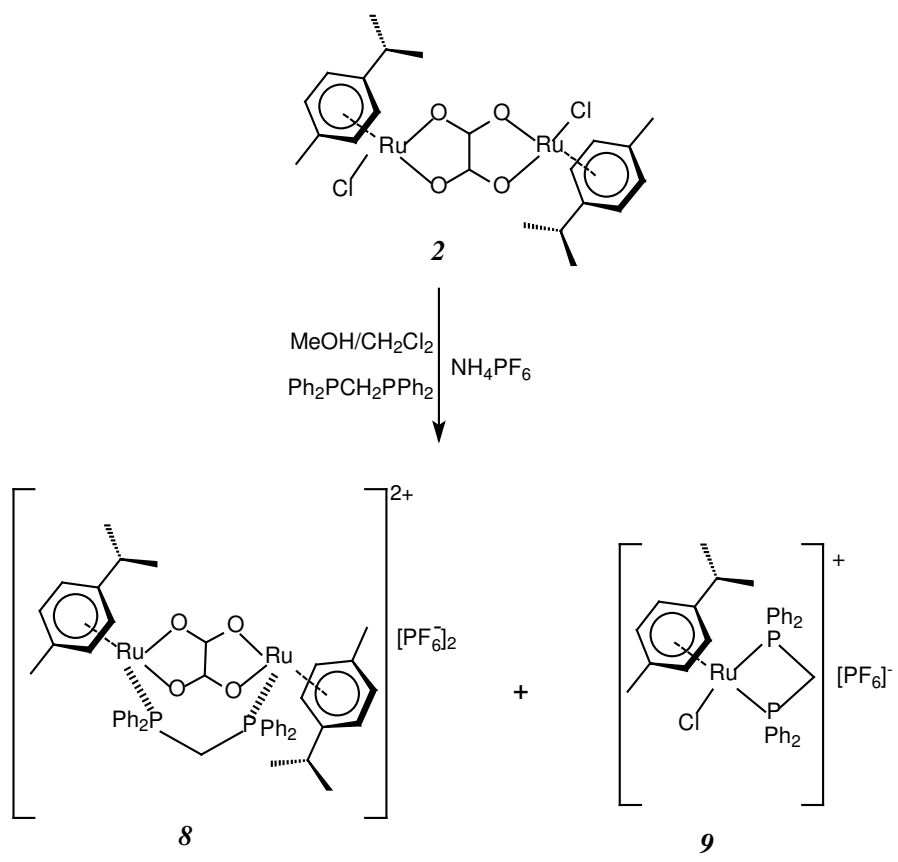

Figure 8. Scheme of formation of complexes (8 and $\mathbf{9})$.

Complex 2 was treated with an equimolar amount of dppm at room temperature, in $\mathrm{CH}_{2} \mathrm{Cl}_{2} / \mathrm{MeOH}$ in the presence of two equivalents of $\mathrm{NH}_{4} \mathrm{PF}_{6}$. The brown solid isolated proved 
to be a mixture of the expected complex $\mathbf{8}$ and $\mathbf{9}$. Attempts to separate $\mathbf{8}$ and $\mathbf{9}$ by recrystallization in mixed $\mathrm{CH}_{2} \mathrm{Cl}_{2}$ /hexane failed. 9 can be readily prepared by reacting the dimer $\left[\mathrm{RuCl}_{2}\left(\eta^{6}-p \text {-cymene }\right)\right]_{2}$ at room temperature with an equimolar amount of $\mathrm{dppm}$, in $\mathrm{CH}_{2} \mathrm{Cl}_{2} / \mathrm{MeOH}$ in the presence of $\mathrm{NH}_{4} \mathrm{PF}_{6}$.

The IR spectrum of the solid mixture gives peaks at $1624\left(v_{\mathrm{as}(\mathrm{OCO})}\right)$ and $839\left(v_{\mathrm{PF}} \mathrm{Of}_{\mathrm{PF}_{6}}{ }^{-}\right)$. A change is observable in the shape of the $v_{\text {as(OCO) }}$ band. Perfectly symmetrical in the IR spectrum of 2 , it becomes irregular, without being split, with the appearance of two shoulders before 1700 $\mathrm{cm}^{-1}$ at 1680 and $1660 \mathrm{~cm}^{-1}$. This connotes the effect of the ligand dppm once bonded to the $\mathrm{Ru}(\mathrm{II})$. Hence, we can state that the four oxygen atoms of the oxalate remain bonded to the $\mathrm{Ru}(\mathrm{II})$ as in $\mathbf{2}$. Only, it is noticeable that the observed asymmetry in the form of the $v_{\mathrm{as}(\mathrm{OCO})}$ band would indicate an oxalate ligand slightly bent from planarity to minimize interactions, similarly to an umbrella arrangement and owing to the closeness of the $\mathrm{PPh}_{2}$ groups [21]. Hence, this would induce a difference in the perturbation of the oxygen atoms in the limits of that observable for the ligand in a $\mathrm{C}_{2} \mathrm{v}$ symmetry group.

The NMR spectroscopy gives a best account of the mixture of complexes $\mathbf{8}$ and $\mathbf{9}$. After subtraction of the peaks due to the protons of $\mathbf{9}$, triplet at $\delta_{\mathrm{H}} 4.3$ (vs. $\delta_{\mathrm{H}} 5.6(\mathrm{dt})$ and $4.7(\mathrm{dt})$ of $\mathbf{9}$ ) is attributable to the methylenic protons of the bridged ligand dppm of $\mathbf{8}$. The isopropylic proton of $\mathbf{8}$ appears at $\delta_{\mathrm{H}} 2.3$ (vs. 2.4 of $\mathbf{9}$ ). Therefore, in the case of $\mathbf{8}$, this signal does not occur as two peaks as observed for $\mathbf{2}$ and $\mathbf{7}$, despite the presence of the oxalate ligand. This implicates the chloride interaction within the isopropylic proton in $\mathbf{2}$ and $\mathbf{7}$ as the source of this peak doubling. The ${ }^{31} \mathrm{P}\left\{{ }^{1} \mathrm{H}\right\}$ NMR spectrum shows the typical multiplet of the anion $\mathrm{PF}_{6}{ }^{-}$at $\delta_{\mathrm{P}}-143.04$ and a signal at $\delta_{\mathrm{P}} 25.86$ due to the phosphorous nuclei of the bridging dppm ligand of $\mathbf{8}$. This is in addition to the peak at $\delta_{\mathrm{P}} 3.23$ which is characteristic of the chelating dppm ligand in 9 . The ${ }^{31} \mathrm{P}$ intensity ratios of these two peaks reveal that the mixture is composed of $44.5 \%$ of complex 8 and $55.5 \%$ of 9 .

Complex $\left\{\left[R u\left(\eta^{6}-p \text {-cymene }\right)\left(\eta^{2}-d p p m\right)\right]_{2} \cdot\left(\mu-\eta^{2}-C_{2} O_{4}\right)\right\}\left[P F_{6}\right]_{2}(\mathbf{1 0})$

The reaction of two equivalents of complex 9 with one equivalent of $\mathrm{C}_{2} \mathrm{O}_{4}[\mathrm{TMN}]_{2}$ at room temperature, in $\mathrm{CH}_{2} \mathrm{Cl}_{2} / \mathrm{MeOH}$, resulted in the formation of complex $\mathbf{1 0}$ that was isolated as an air-stable yellow solid (49\% yield) (Figure 9). Complex 10 is soluble in the usual organic solvents and was characterized by microanalysis, IR and NMR $\left({ }^{1} \mathrm{H},{ }^{31} \mathrm{P}-\left\{{ }^{1} \mathrm{H}\right\}\right)$ spectroscopies (details are given in the Experimental section).

In addition to the expected absorption for the $\mathrm{PF}_{6}{ }^{-}\left(839 \mathrm{~cm}^{-1}\right)$, the IR spectrum of $\mathbf{1 0}$ exhibits a strong band $\left(v_{\mathrm{as}(\mathrm{OCO})}\right)$ split into two components at 1651 and $1625 \mathrm{~cm}^{-1}$ due to the coordinated oxygen atoms of the oxalate. The shoulder at $1700 \mathrm{~cm}^{-1}$ matches the stretching vibrations $\left(v_{(\mathrm{C}=0)}\right)$ of non-coordinated $\mathrm{C}=\mathrm{O}$ bonds. The appearance of this shoulder and the splitting of the $v_{\mathrm{as}(\mathrm{OCO})}$ vibration are in accordance with the $\mathrm{C}_{2} \mathrm{v}$ symmetry group of the oxalate.

The most remarkable feature of the ${ }^{1} \mathrm{H}$ NMR spectrum is the unresolved two multiplets at $\delta_{\mathrm{H}}$ 5.8 and 4.6 that was expected for the characteristic two triplet resonances of the methylenic protons. The resolution of these two signals, compared to those found in the ${ }^{1} \mathrm{H}$ NMR spectrum of $\mathbf{9}$, is related to the electron-withdrawing of the oxalate. In comparison to the NMR data of $\mathbf{2}$ and $\mathbf{7}$, the ${ }^{1} \mathrm{H}$ NMR spectrum of $\mathbf{1 0}$ shows only one unique signal at $\delta_{\mathrm{H}} 2.5$ due to the isopropylic proton. Thus, we conclude that $\mathbf{1 0}$ does not possess conformational isomers like derivatives $\mathbf{2}$ and 7. Further, 10 displays in its ${ }^{31} \mathrm{P}-\left\{{ }^{1} \mathrm{H}\right\}$ NMR spectrum a singlet at $\delta_{\mathrm{P}} 3.96$ that is shifted to lower frequency compared to the peak due to the phosphorus nuclei of the chelating dppm in 9 (3.23 ppm). This is anticipated, given the deshielding effect of the carboxylate groups. The multiplet at $\delta_{\mathrm{P}}-143.04$ is associated with the $\mathrm{PF}_{6}{ }^{-}$anion.

The spectroscopic data of $\mathbf{1 0}$, as well as its elemental analysis, are consistent with the proposed structure in Figure 9.

Bull. Chem. Soc. Ethiop. 2008, 22(2) 


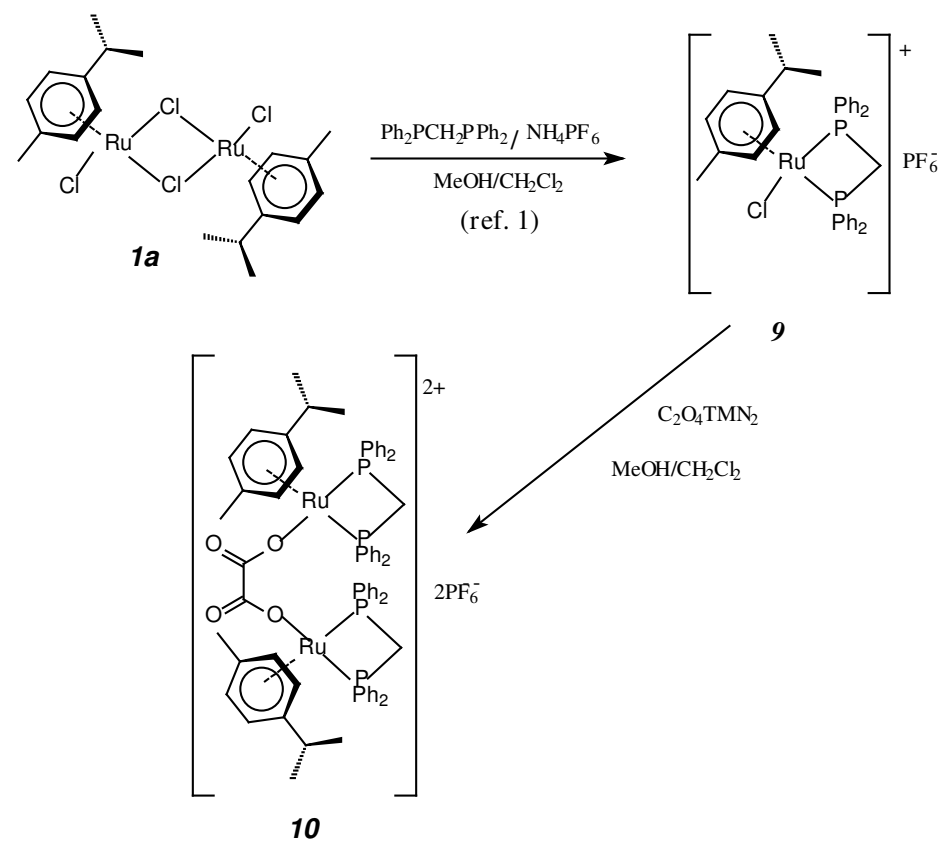

Figure 9. Scheme of formation of complexes (10).

\section{CONCLUSIONS}

This paper has shed more light on the complex $\left[\mathrm{RuCl}\left(\eta^{6}-p \text {-cymene }\right)\right]_{2} \cdot\left(\mu-\eta^{4}-\mathrm{C}_{2} \mathrm{O}_{4}\right)$. The ${ }^{1} \mathrm{H}$ NMR spectra have revealed the existence of two conformational isomers for this and related complexes. Further reaction of dppm, with $\left[\mathrm{RuCl}\left(\eta^{6}-p \text {-cymene }\right)\right]_{2} \cdot\left(\mu-\eta^{4}-\mathrm{C}_{2} \mathrm{O}_{4}\right)$ generates $\left[\operatorname{RuCl}\left(\eta^{6}-\mathrm{p}\right.\right.$-cymene $\left.)\left(\eta^{2}-\mathrm{dppm}\right)\right]\left[\mathrm{PF}_{6}\right]$, in addition to the expected binuclear $\left[\mathrm{Ru}\left(\eta^{6}-\mathrm{p}-\right.\right.$ cymene $\left.)]_{2}\left(\mu-\eta^{4}-\mathrm{C}_{2} \mathrm{O}_{4}\right)(\mu-d p p m)\right]\left[\mathrm{PF}_{6}\right]_{2}$ complex. Additionally, this study has revealed a difference in the reactivity of $\left[\mathrm{RuCl}_{2}\left(\eta^{6}-p \text {-cymene }\right)\right]_{2}$ and $\left[\mathrm{RuCl}_{2}\left(\eta^{6} \text {-mesitylene }\right)\right]_{2}$ toward the oxalate ligand. Investigations on the synthesis and the reactivity of other $\left[\eta^{6}\right.$-(methylsubstituted)arene] $\mathrm{Ru}(\mathrm{II})$ oxalato complexes to further verify the proposed structures are in progress in our laboratory.

\section{AKNOWLEDGEMENTS}

The corresponding author is indebted to Prof. Jacques Brocard of the Universite de Lille 1, and all the researchers of his team, Prof. Pierre H. Dixneuf and Prof. Daniel Touchard of the Université de Rennes 1 for their enthusiastic welcome on the occasion of his work practices in their respective laboratories. He also wishes to thank Dr Abdou Ngom of the Département d'Anglais/Faculté des Lettres et Sciences Humaines and Madame Seynabou Ndiaye Dieng of the Association Culturelle Senegal USA for their precious linguistic proficiency. 


\section{REFERENCES}

1. Gaye, M.; Ndiaye, C.M.; Samb, A. Bull. Chem. Soc. Ethiop. 1993, 7, 117.

2. Ndiaye, C.M. Thèse de Doctorat $3^{\text {ième }}$ cycle, Université Cheikh Anta Diop de Dakar, Sénégal, 1993.

3. Yan, H.; Süss-Fink, G.; Neels, A.; Stoeckli-Evans, H. J. Chem. Soc., Dalton Trans. 1997, 4345.

4. Dale, S.H.; Elsegood, M.R.J. Acta Cristallogr. 2006, 62, m166.

5. For more details, see the following reviews: Le Bozec, H.; Touchard, D.; Dixneuf, P. Adv. Organomet. Chem. 1989, 29, 163; Bennett, M.A. in Comprehensive Organometallic Chemistry II; Vol. 7, Abel, E.W.; Stone, F.G.; Wilkinson, G. (Eds.); Elsevier: Oxford, 1995, p 549.

6. Govindaswamy, P.; Linder, D.; Lacour, J.; Süss-Fink, G.; Therrien, B. Chem. Commun. 2006, 4691.

7. Bruneau, C.; Dixneuf, P.H.; Ruthenium Catalysts and Fine Chemistry, Springer-Verlag: New York; 2004

8. Representative articles: Fürstner, A.; Picket, M.; Bruneau, C.; Dixneuf, P.H. Chem. Commun. 1998, 1315; Dyson, P.J.; Ellis, D.J.; Parker, D.G.; Welton, T. Chem. Commun. 1999, 25; Fürstner, A.; Liebl, M.; Lehmann, C.W.; Picquet, M.; Kunz, R.; Bruneau, C.; Touchard, D.; Dixneuf, P.H. Chemistry A. Europ. J. 2000, 6, 1847.

9. Davies, D.L.; Fawcett, J.; Garatt, S.A.; Russell, D.R. Chem. Commun. 1997, 1351.

10. Thoumazet, C.; Melaimi, M.; Ricart, L.; Mathey, F.; Le Floch, P. Organometallics 2003, 22 , 1580.

11. For more details, see the following reviews: Melchart, M.; Sadler, P.J. in Bioorganometallics; Jaouen, G. (Ed.); Wiley-VCH: Germany; 2006; p 39; Ang, W.H.; Dyson, P.J. Eur. J. Inorg. Chem. 2006, 4003; Yan, Y.K.; Melchart, M.; Habtemariam, A.; Sadler, P.J. Chem. Commun. 2005, 4764.

12. Ang, W.H.; Daldini, E.; Scolaro, C.; Scopelliti, R.; Juillerat-Jeannerat, L.; Dyson, P.J. Inorg. Chem. 2006, 45, 9006.

13. Bennett, M.A.; Huang, T.N.; Matheson, T.W.; Smith, A.K. Inorg. Synthesis 1982, 21, 74; Bennett, M.A.; Smith, A.K. J. Chem. Soc., Dalton Trans. 1974, 233.

14. Bennett, M.A.; Ennett, J.P.Organometallics 1984, 3, 1365; Brunner, H.; Zwack, T.; Zabel, M.; Beck, W.; Böhm, A. Organometallics 2003, 22, 1741.

15. Krisnamurty, K.V.; Harris, G.M. Chem. Rev. 1961, 61, 213.

16. Albert, B.; Jansen, M. Zeitsch. Anorg. Allgem. Chem. 2004, 621, 1735.

17. Chatt, J.; Mann, F.G.; Wells, A.F. J. Chem. Soc. 1938, 2087; Hester, R.E.; Gressman, W.E.L. Inorg. Chem. 1966, 5, 1308; Cheng, P.-T.; Loescher, B.R.; Nyburg, S.C. Inorg. Chem. 1971, 10, 1275; Scott, K.L.; Wieghardt, K.; Skyes, A.G. Inorg. Chem., 1973, 12, 655.

18. Le Floch, F.; Sala-Pala, J.; Guerchais, J.E. Bull. Soc. Chim. Fr. 1975, 120.

19. Tocher, D.A.; Gould, R.O.; Stephenson, T.A.; Bennett, M.A.; Ennett, J.P.; Matheson, T.W.; Sawyer, L.; Shah, V.K. J. Chem. Soc., Dalton Trans. 1983, 1571.

20. Ben Rhaiem, A.; Hlel, F.; Guidara, K.; Gargouri, M. Spectrochim. Acta Part A 2007, 66, 1107.

21. Arthur, H.R. Jr.; Peterson, S.W. Ann. New York Acad. Scien. 1978, 313, 560; Manceron, L.; Loutellier, A.; Perchard, J.P. J. Molecular Struct. 1985, 129, 115; Nakamoto, K. Infrared and Raman Spectra of Inorganic and Coordination Compounds, $4^{\text {th }}$ ed., John Wiley and Sons: New York; 1986; p 248. 